\title{
先天外斜視を合併したRubinstein一Taybi症候群の一例
}

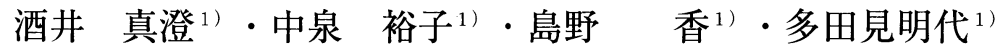

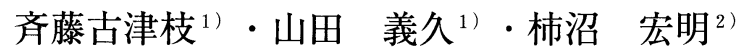

1) 金沢医科大学眼科

2) 金沢医科大学小児科

\section{A case of Rubistein-Taybi syndrome with congenital exotropia}

\author{
Masumi Sakai ${ }^{1)}$, Hiroko Nakaizumi ${ }^{1)}$, Kaori Shimano ${ }^{1)}$, Akiyo Tatami ${ }^{1)}$ \\ Kotue Saitou $^{1)}$, Yoshihisa Yamada ${ }^{1)}$, Akihiro Kakinuma ${ }^{2)}$ \\ 1) Department of Opthalmology,Kanazawa Medical University \\ ${ }^{2)}$ Department of Pediatrics, Kanazawa Medical University
}

\begin{abstract}
要 約
Rubinstein-Taybi症候群は、種々の眼症状を合併することが知られている。本症候群に先天外斜 視を合併した一例を経験したので報告する。

症例は 3 歳の男児。生後 3 か月頃より外斜視を認め、 1 歳 9 か月時、 2 歳 7 か月時に外斜視に対 し手術を受け一旦は正位となったが、第 2 回目手術後 1 年の観察時点で再び $15^{\circ}$ の外斜視となった。 本症例は 2 度の手術後でも眼位の安定は得られなかった。眼位の安定化不良の原因として手術時 期の遅れ、精神発達遅延などが考えられた。
\end{abstract}

\footnotetext{
別冊請求先（９20-0293）石川県河北郡内灘町大学 $1-1$ 金沢医科大学眼科 酒 井 真 澄

Tel. 076-286-3511 Fax. 076-286-1010

Key words : Rubinstein-Taybi症候群, 先天外斜視, 斜視手術, 精神発達遅延, Rubinstein-Taybi syndrome, congenital exotropia, strabismus surgery, mental retardation
} 


\begin{abstract}
The Rubinstein-Taybi syndrome combined with various ophthalmic diseases has been published in reports. In this present study we present a case of Rubinstein-Taybi syndrome with congenital exotropia.

A four year old boy was diagnosed with exotropia 1 month after birth. Two operations were performed, one at 1.7 and the after at 2.5 years of age. 6 months after the second surgery, exotropia increased again and subsequently lead to 15 degree constant exotropia. Now, we are following him up in our clinic.

Generally, it has been reported that treatment at the early stage helps to keep ocular alignment. However, the eye position was not stabilized after the second surgery in our case. The cause of poor of ocular alignment may be accounted for by correlation with various factors such as the age at the time of surgery, mental retardation and so on.
\end{abstract}

\section{I．緒言}

Rubinstein -Taybi症候群は、太く幅広い拇指 と両下肢第 1 指、特異な顔貌、精神運動発達遅 延、低身長を特徴とする奇形症候群 ${ }^{1)}$ で、眼科 的所見は緑内障、白内障、屈折異常、虹彩およ び脈絡膜欠損、眼球陥没など ${ }^{2)}$ 多彩であるが本 邦での報告例は少ない。斜視の合併の報告はあ るが3、外斜視の合併例はほとんどない。今回、 著者らはRubinstein -Taybi症候群に先天外斜視 を合併した1例を経験したので報告する。

\section{II. 症例}

\section{患 者：4歳 男児}

主 訴: 眼位異常

既往歴：在胎38週 2 日、生下時体重 $3,000 \mathrm{~g}$ で妊 娠中特記すべき異常はなかった。出生時、両拇 指拉よび両下肢第一指の巨指症、高口蓋、小睪 丸、鼻中隔湾曲など多発奇形を認め、当院小児 科でRubinstein-Taybi症候群と診断された。 家族歴：母親に 1 度の自然流産、子宮外妊娠の ため 1 度の人工流産歴があった。

全身所見：顔貌は多毛で内眼角開離、逆蒙古様 瞼裂がみられ、大泉門開大、鼻中隔湾曲、耳介 変形を認め、両側拇指は近位指節関節より外側 へ屈曲・変形し幅広く、両下肢第1趾は偏平であ り、精神発達遅延を認めた。

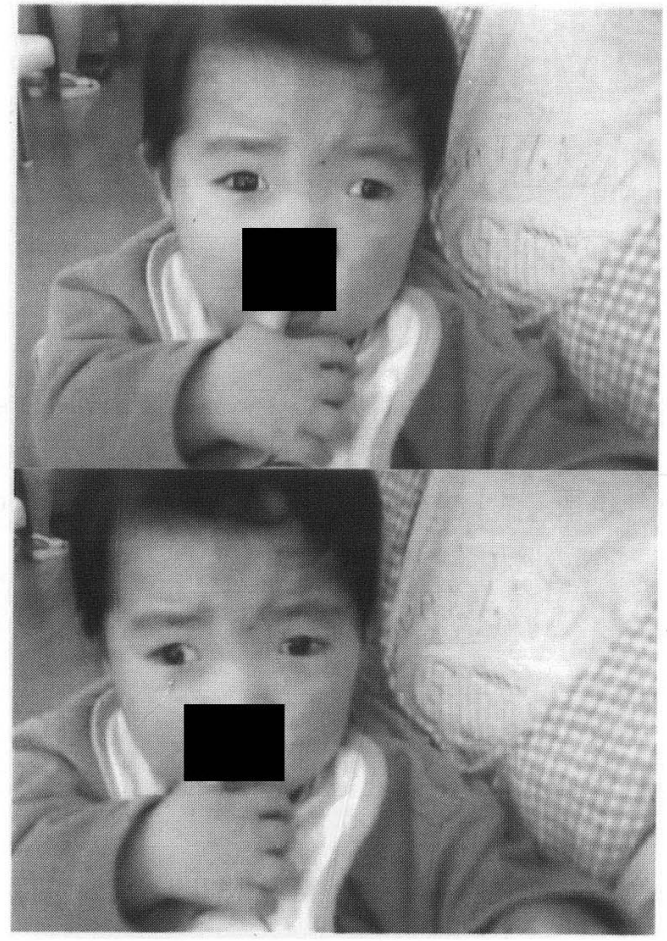

図 1 . 術前眼位 交代固視可能

眼科的所見 : 視力は P L 視力で、両眼 0.075 と左 右差はなかった。調節麻痺下（硫酸アトロピン $0.5 \%$ 点眼）での他覚的屈折検査值は、右眼 + $2.5 \mathrm{D}$ 、左眼 $+3.5 \mathrm{D}$ であった。眼圧は麻醉下で右 眼 $15 \mathrm{mmHg}$ 、左眼 $13 \mathrm{mmHg}$ であった。眼位は 
Hirschberg法で $15^{\circ}$ の外斜視があり、交代固視 は可能であった（図 1 ）。眼球運動は正常であ った。角膜径は両眼ともに $10 \mathrm{~mm} て ゙ 、$ 虹彩、脈絡 膜欠損はなかった。前眼部、中間透光体には異 常は認められなかった。眼底は、視神経乳頭の C/D比が右 0.8 、左0.7であったが色調は良好で辺 縁の欠損はなかった。後極部、周辺網膜には明 らかな異常はなかった（図 2)。

経過：交代固視は可能であり、PL視力では両眼 視力に左右差はなかったため、 1 歳 8 か月時、

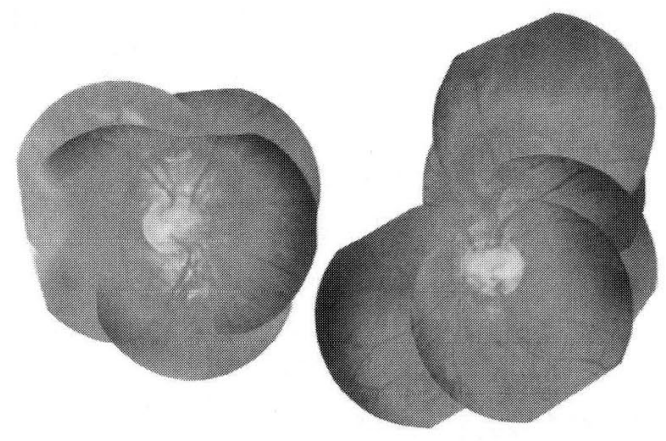

図 2. 左: 右眼 右: 左眼 の眼底写真

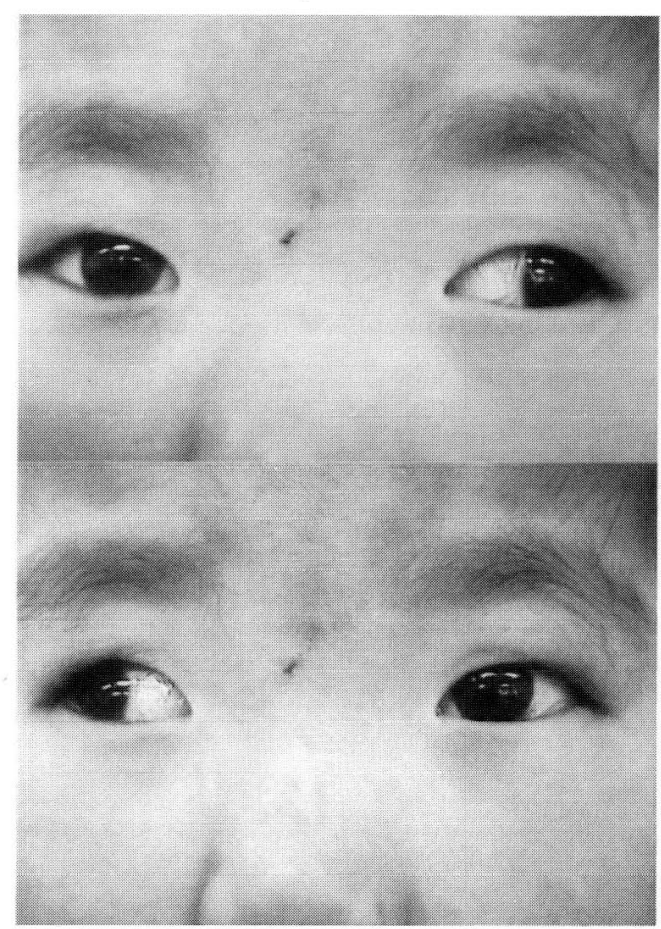

図 3. 再手術前眼位 交代固視 可能

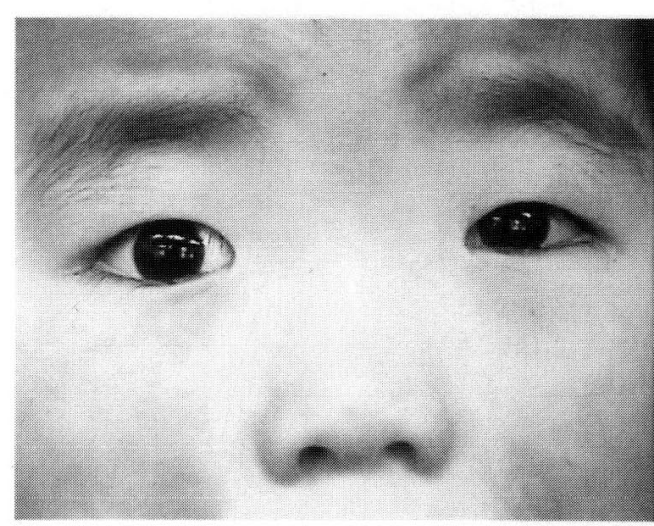

図 4.再手術后10日目の眼位

小児外科での腹腔鏡下精巣固定術施行時に眼科 手術（右眼内直筋 $5 \mathrm{~mm}$ 短縮、外直筋 $6 \mathrm{~mm}$ 後転術） を同時に行った。術後 3 か月時点では Hirschberg法で $5{ }^{\circ}$ の外斜視であったが、手術 後1年経過では、Hirschberg法で30 の外斜視、 Krimsky法で55 60 $\Delta$ の外斜視となった (図 3 )。 初回手術より 1 年 1 か月後 ( 2 歳 8 か月時)、 左眼内直筋 $7 \mathrm{~mm}$ 短縮、外直筋 $8 \mathrm{~mm}$ 後転術を施行 した。術後10日目の眼位は、Hirschberg法でほ ぼ正位であった（図 4 ）。再手術後1年では Hirschberg法で $15^{\circ}$ の外斜視、Krimsky法で30 $\Delta$ の外斜視となっていた。 2 歳 8 か月時点での 視力は、 P L 視力で両眼0.1と左右差はなかっ た。調節麻痺下（塩酸シクロペントレート点眼） での他覚的屈折検査值は、右眼：+2.5D cyl+ $3.5 \mathrm{Daxis} 177^{\circ} \quad$ 左眼: + $1.0 \mathrm{D} \mathrm{cyl}+$ $3.0 \mathrm{Daxis} 180^{\circ}$ であり、4墄になった時点でも、 眼位はHirschberg法で $15^{\circ}$ の外斜視、Krimsky 法で30 $\Delta$ の外斜視であり、視力はグレーティン グカードで両眼眼鏡装用にて、0.29である。遠 視と乱視に対し眼鏡装用し、交代遮蔽による弱 視訓練をして現在に至っている。

\section{III. 考案}

Rubinstein-Taybi症候群は1963年にRubinstein とTaybiが「太く幅広い拇指および第1趾と特異 な顔貌」を特幑とする種々の全身奇形を伴う症 候群として提唱した疾患で、多彩な眼症状を合 併することが知られているが、他に逆蒙古様臉 
表 1. Rubinstein-Taybi症候群の主症状

症 状

後藤らの報告での出現率

本症例での出現

\begin{tabular}{|l|c|c|}
\hline 反復性呼吸器感染 & 64 & + \\
\hline 哺乳障害 & 93 & + \\
\hline 幅広い鼻橋 & 86 & + \\
\hline 鈎鼻 & 86 & + \\
\hline 高口蓋 & 92 & + \\
\hline 内眼勇離 & 92 & + \\
\hline 逆蒙古状眼裂 & 62 & + \\
\hline 斜視 & 43 & + \\
\hline 白内障 & 12 & - \\
\hline
\end{tabular}

裂、内眼角開離、小頭症、耳介低位、心奇形、 小顎、反復性呼吸器感染、透明中隔欠損、発育 障害、精神発達遅延などがみられる（表 1 ）。 病因は不明で、染色体異常を伴った症例報告 ${ }^{4)}$ もあるが、核型は決まっておらず多因子性遺伝 が疑われる。

先天外斜視は比較的まれな合併症であり検索 の限りその報告は少ない。後藤らは、14例の Rubinstein-Taybi症候群について報告しており、 そのうちの $43 \%$ に斜視の合併を認めているが、 眼位異常の内訳についての記載はない ${ }^{3)} 。$ 本症 例は先天外斜視を合併していた点で、きわめて 稀な症例と考えられた。本症例は手術後一時的 に眼位は正常化したが、早期にもどりがみられ た。精神発達遅延のため術後の検査が十分に行 えず、眼鏡装用も不十分であったことがその原 因の 1 つとも考えられる。先天外斜視では早期 手術が眼位の安定化を図るとされているが、本 症例は初診時すでに 1 歳 6 か月であったため初 回手術が 1 歳 8 かと遅かったことも眼位のも どりの一因であろう。これまで、RubinsteinTaybi症候群に合併した斜視に対しての手術報 告は著者らの検索した限りではないがおそらく、
本疾患が $100 \%$ 精神発達遅延を合併し、術後の両 眼視機能の獲得が困難であるためと考えられる。

本症例では斜視手術を施行したが、手術の適 応については慎重な検討が必要であると考える。 山口ら ${ }^{5)}$ 、佐野ら ${ }^{6)}$ は本症候群に先天性緑内障 を合併した症例を報告している。本症例も視神 経乳頭陥凹の拡大から緑内障が疑われたが、眼 圧が全麻下ではあるが、右眼 $15 \mathrm{mmHg}$ 、左眼 $13 \mathrm{mmHg}$ であること、隅角に明らかな異常はな く、角膜径が両眼ともに $10 \mathrm{~mm}$ と正常であったこ となどから現時点では緑内障への積極的な治療 は行っておらず、乳頭所見の変化等より今後引 き続き経過観察していく。

\section{参考文献}

1 ) Rubinstein, J. H.andTaybi, H. : Broad Thumbs and Toes and Facial Abnormalities, Am. J. Dis. Child. $105: 588,1963$

2 ）八子恵子: Rubinstein-Taybi症候群 1 例, 眼 科, $15: 889-892,1973$

3 ）後藤英士 他：Rubinstein-Taybi症候群の眼 症状について, 眼臨, $67: 832,1973$.

4) Wulfsberg EA, Klisak IJ, Sparkes RS : High Resolution chromosome banding in the Rubinstein-Taybi syndrome. Clin Genet 23 : 35-37, 1983

5 ）山口慶子他：先天性緑内障を合併した Rubinstein-Taybi症候群, 臨眼, $45: 678-$ 679, 1991

6）佐野秀一 他：先天性緑内障を合併した Rubinstein-Taybi症候群の 1 例, 臨眼, 46 ： 694-695, 1992 